\title{
Himalayan perceptions: Environmental change and the well-being of mountain peoples
}

\author{
Fifteen years ago, the Himalayan Dilemma buried the most popular \\ environmental paradigm of the $80 \mathrm{~s}$. What will it take for policy-makers to \\ get the message?
}

J ack D lves

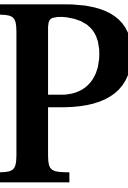

erceptions of environmental change affecting the Himalayan region have undergone extensive revision over thelast thirtyyears. During the first half of this period it had been widely assumed that environmental collapsewasimminent dueto exponential increase in pressure on the natural resources driven by rapid population growth and deepening poverty. One of the manystatements of imminent catastrophe was issued by the World Bank in 1979, predicting that by the year 2000 all accessible forest in Nepal would be eliminated. Although thelinkageof human poverty and natural disaster continues to attract serious debate, the catastrophist paradigm has been discredited by an avalanche of research, not to mention the passage of timeduring which theheralded disaster has failed to materialize. This has opened the way for a more realistic appraisal of theactual dynamics of change in theregion.

The publication of The Himalayan Dilemma (Ives and Messerli 1989)²fifteen years ago derived from an international conference on the 'Himalaya-Ganges Problem' held at Mohonk Mountain House, New York State, in May 1986. The conference had been called to investigate the validity of the prevailing Himalayan environmental paradigm of the 1970s and 1980s that cameto beknown astheTheory of Himalayan Environmental Degradation. In brief, the Theory proposed that increased devastating flooding on the Ganges and Brahmaputra lowlands was a direct response to extensive deforestation in the Himalaya. Thedeforestation waspresumed to result from a rapid growth in the mountain subsistence farming populations dependent on the forests for fodder and fuel and for conversion to terraced agriculture. Assteep mountain slopeswere denuded of forest cover, it was assumed that the heavy monsoon rains caused accelerated soil erosion, numerous landslides, and increased runoff and
Himalayan perceptions:

Environmental change and the well-being of mountain peoples

by J D Ives

Routledge, London and New York

To be published in August 2004

sedimenttransfer onto the plains. Thiswas further assumed to induce a progressive increasein flooding of Gangetic I ndia and Bangladesh, putting at risk the lives of several hundred million people.

The 1986deliberationswerefrequently heated, but a consensus was reached to the effect that the Theory lacked scientific substantiation. Thiswas reflected in the1989 book; we stressed, however, that a great deal of more focused and more rigorous empirical research was required in order to substantiate the many issues that had been raised. The Himalayan Dilemma, whileeffectivelycontestingmany unproven assumptions that collectively formed the Theory, could be seen as essentially an attempt to prove a series of negatives. Nevertheless, theacademic responseto the book was generally positive and it is still quoted in almost every scholarly publication on the Himalayan region. Forsyth (1996) ${ }^{3}$ credited the Mohonk Conference with achieving the first major environmental paradigm shift and, along with Thompson (1995) ${ }^{4}$, referred to the unfolding discourse as The Mohonk Process.

Despite the positive reception on the part of academics, the perceptions generated bytheMohonkProcesshad little impact on environmental policies. Regional authorities, for example, to this day maintain embargoes on loggingin the mountains based on the justification that extensive deforestation was causing seri-

Himalayan Perspectives returns to the enormously popular development paradigm that Ives dubbed the 'Theory of Himalayan Degradation'. According to this seductive construct, poverty and overpopulation in the Himalayas was leading to degradation of highland forests, erosion, and downstream flooding. In the 'Himalayan Dilemma', Ives and Messerli exposed this "Theory" as a dangerous collection of assumptions and misrepresentations. While most scholars in the field promptly conceded Ives and Messerli's points, the Theory has somehow survived as the guiding myth of development planners and many government agencies. In his new book, Ives returns to drive a stake through the heart of this revenant. His book not only reviews the research that, over the past 15 years, has confirmed the arguments of the 'Himalayan Dilemma'; it also takes a close look at all those destructive factors that were overlooked by the conveniently simplistic 'Theory of Himalayan Environmental Degradation': government mismanagement, oppression of mountain minorities, armed conflict, and inappropriate tourism development. 
ousfloodingand major dislocationsdownstream.

Since 1989, and partly as an outcome of the Mohonk Conference, a vast amount of related environmental research hasbeen undertaken; its publication, however, has been scattered widely throughout the literature. The new book, therefore, attemptsto bring together and analyzethe more recent studies in the context of the earlier work that led up to the 1989 publication. It presents a final rejection of the earlier environmental paradigm; this becomes the more important considering the inappropriate environmental and developmental policy decisions to which the region is still subjected. Furthermore, the inept and sustained focus of much of the government legislation has served to paint the poor mountain minority people as the prime cause of environmental degradation and so deflect attention from the real problems.

$\mathrm{H}$ imalayan Perceptions has two primaryaims: oneisto follow through on theacademic discourse, to examinethe results of the post-1989 research, and thus to update The Himalayan Dilemma; the second is to assess the problems that threaten the stability of the region as the new century unfolds. As a corollary to this, someof the reasonswhyscholarly research has had little, or no, inherent impact on environmental policy making are discussed. In particular, the perpetration of disaster scenarios by the news media is explored because it is believed that this is one of the reasons why the public at large still accepts the notion of impending environmental catastrophe.

Theregion discussed hereextendswell beyond the limits of the Himalaya sensu stricto (the2,500 kilometrearc from Nanga Parbat, above the middle Indus Gorge in the northwest, to Namche Barwa, above theYarlungtsangpo-BrahmaputraGorgein the east). Coverage is extended to include the Karakorum, Hindu Kush, and Pamir mountains in the northwest, and the Hengduan Mountains of Yunnan, the mountains of Northern Thailand, and the ChittagongHill Tracts, in thesoutheast. The United Nations University(UNU) mountain research project, fromitsinitiation in 1978, hasinvestigated test areasthroughout this broader region, and the new book represents a contribution that concludes the quarter century of UNU effort.

Himalayan Perceptions attempts to analyze the manner in which the perceptions of theHimalayan region haveevolved over thelast threedecades. It exploreshow the simplistic environmental alarm arose and why it held sway for so long. Without doubt, the environmental problems assumed to be threatening the region in the 1970 s and 1980 s were causing widespread concern and affected the way in which international aid was manipulated. Over the lastfifteen yearsithas becomeincreasingly clear that the more dominant causes of instabilityaresocio-economic, administrative, political, and the spread of violence and terrorism. The continued debilitating poverty is regarded, at least in part, as a consequence of mismanagement in its broadest sense. Therefore, in addition to assessinghow theenvironmental discourse has played out since 1989, issues involving poverty, oppression of the mountain peoples, unequal access to resources, insurgency, and military conflict are presented. The importance of tourism is also addressed because it is a major forcethat has both positive and negative aspects and is now menaced in many places bythegrowing political tensions and violence in the region.

I have tried to write in the spirit of the United Nations General Assembly of 1997 (Rio-Plus-Five), convened in order to evaluate the progress achieved in the five yearsfollowingthe1992Rio deJaneiroEarth Summit (UNCED), and of theUN designation of 2002 as the International Year of Mountains (IYM). Since the primary goal of IYM is 'sustainable mountain development', it is considered that prospects for achieving this goal, at least within the Himalayan region, will be limited by the degree to which the problems can becorrectly defined. If progress has been made towards producing a more accurate definition then thewriting of thebook will have been well worthwhile.

$T^{T}$ hereareeleven chapters. Chapter One, entitled The Myth of Himalayan Environmental Degradation, provides an overview of how the Himalayan region has been perceived over the last thirty years and of how research has progressively influenced, or failed to influence, efforts to obtain regional 'sustainable development'. It includes a restatement of the Theory of Himalayan Environmental Degradation that was widely publicized by Erik Eckholm's book Losing Ground (1976) ${ }^{5}$. This is followed by a review of the later Himalayan environmental research, in effect, a synthesis of the first of the book's main themes. Chapter Two is an outline of the region under discussion - the Himalaya, defined very broadly. Chapter Threeexaminesthediscourseon thestatus of Himalayan forests; it contrasts themore humid eastern and central Himalaya with the increasingly drier conditions as one moves progressivelytoward thenorthwest into Northern Pakistan andTajikistan. Chapter Four, Geomorphology of agricultural landscapes, addresses the complex relationships between land-cover type, especially agricultural terrace types and their management, precipitation, soil erosion, and downstream effects. Chapter Five, entitled Flooding in Bangladesh: causes and perceptions of causes, questions the relationships between land-use/land-cover changes in the Himalaya and flood plain responses. Drawing on extensive recent work by Thomas Hofer and Bruno Messerli6, amongst other studies, it concludes emphatically that the primary cause of flooding in Bangladesh, and by extension in northeast India, is heavy monsoonal rainfall across Bangladesh and adjacent areas of lowland India.

The first five chapters, therefore, expose the Theory of Himalayan Environmental Degradation as an insupportable mental construct that should be totally eliminated as a basis for environmental and developmental policy making. The following five chapters turn attention to some of the actual problems that require far more rigorous attention by governments of the region and by foreign aid and development agencies in general.

Themajor physical hazards that posea challenge to sustainable development in the Himalayas are the concern of Chapter Six; theseinclude earthquakes, landslides, and torrential rainstorms. Opportunity is taken to introduce the controversy concerning construction of the Tehri Dam in relation to seismic hazard assessments, and the exaggerated claims of the dangers posed by the likelihood of catastrophic outburst of glacial lakes. Chapter Seven attempts to assess the development and importance of tourism, its positive and negativeaspects, and the dangersinherent in excessive local dependency on a single development endeavour. Chapter Eight reviews the devastation being caused by accelerating violence - warfare, guerrilla activity, and unconscionable repression of mountain minority peoples. Topics range from actual warfare, as on the Siachen Glacier, Nepal's Maoist Insurgency, Bhutan'shuman rightsabusesperpetrated on its Lhotsampa Hindu minority, Nagalim, and the oppression resulting from the imposition of mega-projects, such as the Tehri and Kaptai dams. Chapter Nine presents an overview of rural change and the challenges facing attempts to decentralize control over access to natural resources. The role of exaggeration - deliberateor unwitting distortion of events that areexasperated by news media reports-is examined in Chapter Ten. Individual case studiesare presented, several of which are 


\section{PUblication PREVIEW}

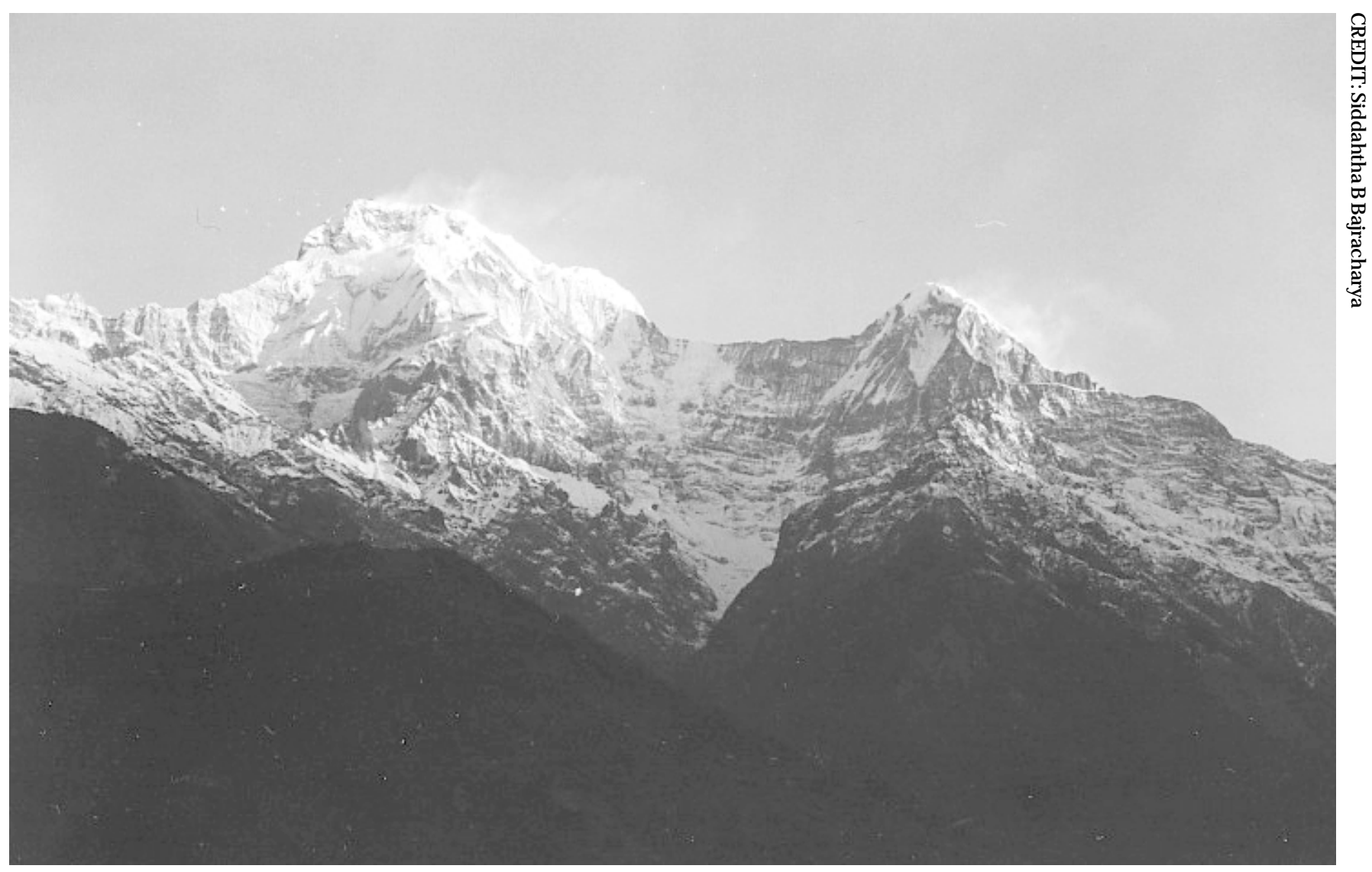

\section{Are the Himalayas really in crisis? And if so, who's to blame?}

shown as examples of distortions, even deliberatefalsehoods, based in part on my experiencein thefield. Theconcludingchapter is styled: Redefining the dilemma; is therea way out?

The book frames the main conclusion that the Theory of Himalayan Environmental Degradation is not only a fallacy, butalso an unfortunateimpediment to identification of the real obstacles to sustainable development. These include administrativeincompetence, corruption, greed, oppression of mountain minority peoples, political in-fighting, and even military and political competition for control of resourcesand strategic locations. The well-being of the 70-90 million mountain peoplehas been largelyneglected and so they are left with little alternative but to exert increasing pressure on whatever natural resources that are accessible, whether legally or illegally.

I have tried to make each chapter as self-contained as possible. Thishasled to a considerable amount of repetition. However, I believe this approach will be most beneficial for thereader who has not had direct experience of the Himalaya. Noneof thetopicshas received an exhaustivetreatment. Rather, by selecting a series of issues I havetried to keep thetask within reasonable limits while ensuring a broad view of this vast and complex mountain region and thechallengesfacingits diverse mountain peoples who deserve far better treatment than they have so far received. Without their direct involvement sustainable mountain development will remain a bureaucratic pipedream.

JD Ives is a senior advisor at Environment and Sustainable Development Programme, The United Nations University, Tokyo, Japan and an honorary research professor at Department of Geography and Environmental Studies, Carleton University, Ottawa, Canada. E-mail: jackives@pigeon.carleton.ca

Thisaccount isasynthesis of thebook with thesametitlethat is dueto bepublished by Routledge (London and New York) in August 2004.

\section{References}

1. World Bank. 1979. Nepal: Development performanceand prospects. Washington, DC:The World Bank. AWorld Bank countrystudy

2. JD Ives and B Messerli. 1989. The Himalayan Dilemma: Reconciling development and conservation. London and New York: Routledge. $324 p$

3. T Forsyth. 1996. Science, myth, and knowledge: Testing Himalayan environmental degradation in Northern Thailand. Geoforum, 27(3): 375-92

4. M Thompson. 1995. Policy-makingin theface of uncertainty: the Himalayas as unknowns. In Chapman GP and M Thompson (eds), Water and thequestfor sustainabledevelopmentin theGanges valley.London: Mansell. p 25-38

5. E Eckholm. 1976. Losing Ground. New York:WW Norton for theWorldwatch Institute

6. THofer and B Messerli. 2002. Floods in Bangladesh:History, dynamics, and rethinkingtheroleof theHimalayas(unpublished manuscript)

\section{ANNOUNCEMENT}

The Himalayan J ournal of Sciences will hold a symposium to discuss issues raised by J ack Ives' forthcoming book, Himalayan Perspectives in Sept 2004. The event will be open to the public. Further details will be published on our Web site and in Mountain Forum. 